\title{
Bibliography
}

\author{
Primary sources
}

\section{Unpublished papers}

Archive of the Institute for Advanced Legal Studies, London:

Council of Legal Education files

Birmingham University Library, Special Collections, Birmingham:

Church Missionary Society Archive

Bodleian Library, Oxford:

Oxford University Archives, Admission Records

British Library, London - India Office Records:

Government of India: Crown Representative: Political Department

Indian States Records

India Office: Public and Judicial Department Records

India Office: Political and Secret Department Records

British Library, London - Private Collections:

Kilbracken, Arthur Godley, 1st Baron Collection

Curzon, George Nathaniel, Marquess Collection

London City Mission:

Minutes of Committee Meetings

Minutes of Disciplinary Committee

London Metropolitan Archives:

Central Criminal Court, Minutes of Evidence (microfilm)

National Archives of the United Kingdom, Kew:

1881 British Census and National Index: England, Scotland, Wales, Channel Islands, Isle of Man, and Royal Navy, CD-ROM set. Salt

Lake City: Church of Jesus Christ of Latter Day Saints, 1999

1901 Census (online) www.1901census.nationalarchives.gov.uk/

Board of Trade files

Home Office files

Lincoln's Inn 'Black Book' (microfilm)

St John's College Archives, Cambridge:

Admission Records

Delhi Mission Papers

University College Library Special Collections, London:

Gilchrist Educational Trust Collection 


\section{Journals and newspapers}

Evangelical Magazine

Indian Magazine

Indian Magazine and Review

Journal of the National Indian Association

London City Mission Magazine

St James Gazette

The Standard

The Times

\section{Official and institutional publications}

Association for the Advancement of Scientific and Industrial Education of Indians. Report of the Association for the Advancement of Scientific and Industrial Education of Indians, 1908.

Baines, J. A. Census Commissioner For India: Report for 1891. London: HMSO, 1893.

Chamier, F. E. A. Report of the Regular Settlement of the Bara Banki District. Allahabad: North-Western Provinces and Oudh Government Press, 1879.

Committee of the National Indian Association, in Conjunction with the Advisory Committee, India Office. Handbook of Information for Indian Students Relating to University Etc. Professional Studies, Etc., in the United Kingdom. London: J. S. Phillips, 1909.

Committee of the National Indian Association. Handbook of Information Relating to University Etc. Professional Studies, Etc., for Indian Students in the United Kingdom, 7th edn. Westminster: Archibald Constable and Company, 1893.

Committee on Distressed Colonial and Indian Subjects, Cd. 5133. 1910.

Gilchrist Educational Trust. The Gilchrist Educational Trust: Pioneering Work in Education, 1865-1930. Cambridge: Cambridge University Press, 1930.

Imperial Conference, 1911 - Papers Laid Before the Conference, Cd. 5745. 1911.

Keith, A. Barriedale (ed.). Speeches and Documents on Indian Policy, 1750-1921. Oxford: Oxford University Press, 1922.

Levi, Leone. Wages and Earnings of the Working Classes: Report to Sir Arthur Bass, M.P. London: J. Murray, 1885.

Macaulay, Thomas Babington Macaulay, Baron. 'Minute Recorded in the General Department', 2 February 1835, in Lynn Zastoupil and Martin Moir (eds), The Great Indian Education Debate: Documents Relating to the Orientalist-Anglicist Controversy, 1781-1843. London: Curzon Press, 1999. 


\section{BIBLIOGRAPHY}

Report and Minutes of the Committee Appointed by the Secretary of State for India to Inquire into the Position of Indian Students in the United Kingdom. London: Eyre and Spottiswoode, 1907.

Risley, Herbert Hope. Census of India, Vol. 1, Ethnographic Appendices: Being the Data Upon Which the Caste Chapter of the Report is Based. Calcutta: Office of the Superintendent of Government Printing, India, 1903.

Strangers' Home for the Natives of India, Arabia, Africa, China, Straits of Malacca, the Mosambique, and the Islands of the South Pacific, Annual Report for the Year 1886. N.p., 1887.

— Annual Report for 1900. London: Edwin Sears and Co., 1901.

— Fortieth Annual Report. N.p., n.d.

United Kingdom, House of Commons. Parliamentary Debates, 4th series.

Weyland, John Matthias. Our Veterans: Life-Stories of the London City Mission. London: S. W. Partridge and Co., 1881(?).

\section{Books, pamphlets and articles}

Aeschylus. Agamemnon, trans Herbert Weir Smyth. Loeb Edition, 1926. Reprint: Cambridge, MA: Harvard University Press, 1999.

Bonarjee, N. B. Under Two Masters. Oxford: Oxford University Press, 1970.

Browning, Oscar. Impressions of Indian Travel. London: Hodder and Stoughton, 1903.

Burne, Owen Tudor. Memories. London: Edward Arnold, 1907.

Fitzpatrick, Sir Dennis. Non-Christian Marriage. N.p, n.d. Reproduced in the Henry Morse Collection, Pamphlets on Political Science and Jurisprudence.

Gandhi, Mohandas K. An Autobiography: The Story of My Experiments with Truth, trans. Mahadev Desai. Boston: Beacon Press, 1957.

Hodgson, Pratt. University Education in England for Natives of India: Considered with a View to Qualify Them for the Learned Professions or the Public Service; and to Create a Class Who Shall Mediate Between the Indian People and Their English Rulers. London: James Ridgway, 1860.

Hutchinson, H. G. (ed.). Private Diaries of the Rt. Hon. Sir Algernon West, G. C. B. London: John Murray, 1922.

Kilbracken, Arthur Godley, First Baron. Reminiscences of Lord Kilbracken. London: Macmillan, 1931.

Lyall, Alfred C. Asiatic Studies: Religious and Social. London: John Murray, 1907.

Lyall, Charles James. Translations of Ancient Arabian Poetry: Chiefly PræIslamic. N.d.; Reprint. New York: Columbia University Press, 1930. 


\section{‘THE BETTER CLASS’ OF INDIANS}

Maine, Henry Sumner. Village-Communities in the East and West: Six Lectures Delivered at Oxford to Which Are Added Other Lectures Addresses and Essays. New York: Henry Holt and Company, 1880.

Nehru, Jawaharlal. Toward Freedom: The Autobiography of Jawaharlal Nehru. New York: John Day Company, 1942.

Oxford and Asquith, Earl of. Memories and Reflections, 1852-1927. London: Cassell and Co., 1928.

Pandian, T. B. England to an Indian Eye: or English Pictures from an Indian Camera. London: Elliot Stock, 1897.

Patel, J. M. Framjee. Stray Thoughts on Cricket. Bombay: Times Press, 1905.

Ramabai, Pandita. The Letters and Correspondence of Pandita Ramabai, ed. A. B. Shah. Bombay: Maharashtra State Board of Literature and Culture, 1977.

— The High-Caste Hindu Woman, 2nd edn. Philadelphia: Jason B. Rogers Printing Co., 1888.

Risley, Herbert Hope. The People of India. 2nd edn 1915; reprint, Delhi: Oriental Books Reprint Corporation, 1969.

Salter, Joseph. The Asiatic in England: Sketches of Sixteen Years Work Among Orientals. London: Seeley, Jackson, and Halliday, 1873.

- The East in the West, or Work Among the Asiatics and Africans in London. London: S. W. Partridge and Company, 1895.

Sen, Keshub Chunder. Keshub Chunder Sen in England: Diaries, Sermons, Addresses, and Epistles, ed. Prem Sundar Basu, 4th Indian edn. Calcutta: Writers Workshop, 1980.

Strachey, John. India. London: Kegan Paul, Trench, Trübner and Co., 1894.

Trevelyan, G. O. The Competition Wallah. London: Macmillan, 1866.

Warren, Max. To Apply the Gospel: Selections from the Writings of Henry Venn. Grand Rapids, MI: William B. Eerdmans, 1971.

\section{Secondary sources}

Adas, Michael. Machines as the Measure of Men: Science, Technology, and Ideologies of Western Dominance. Ithaca: Cornell University Press, 1989.

Alexander, Michael and Anand, Sushila. Queen Victoria's Maharajah: Duleep Singh, 1938-93. New York: Taplinger, 1980.

Ali, Imran. The Punjab Under Imperialism, 1885-1947. Princeton: Princeton University Press, 1988.

Anderson, Benedict. Imagined Communities: Reflections on the Origins and Spread of Nationalism, 2nd edn. New York: Verso, 1991.

Arnesen, Eric. 'Whiteness and the historians' imagination', 


\section{BIBLIOGRAPHY}

International Labor and Working-Class History, 60 (Fall 2001), 3-32. Arnold, David. Colonizing the Body: State Medicine and Epidemic Disease in Nineteenth-Century India. Berkeley and Los Angeles: University of California Press, 1993.

(ed.). Imperial Medicine and Indigenous Societies. Manchester: Manchester University Press, 1988.

- Science, Technology and Medicine in Colonial India. In The New Cambridge History of India, Series 3, Vol. 5. Cambridge: Cambridge University Press, 2000.

Arnstein, Walter L. 'The myth of the triumphant Victorian middle class', Historian, 37:2 (1975): 205-21.

Bartrip, Peter. Themselves Writ Large: The British Medical Association, 1832-1966. London: BMJ Publishing Group, 1996.

Bayly, Susan. Caste, Society and Politics in India from the Eighteenth Century to the Modern Age. Cambridge: Cambridge University Press, 1999.

Beckerlegge, G. 'Professor Friedrich Max Müller and the missionary cause', in Religion in Victorian Britain, Vol. 5, Culture and Empire. Manchester: Manchester University Press, 1997.

'Followers of "Mohammed, Kalee and Dada Nanuk": The presence of Islam and South Asian religions in Victorian Britain', in Religion in Victorian Britain, Vol. 5, Culture and Empire. Manchester: Manchester University Press, 1997.

Best, Geoffrey. Mid-Victorian Britain, 1851-1875. London: Weidenfeld and Nicolson, 1971.

Bhattarcharya, Neeladri. 'Lenders and debtors: Punjab countryside, 1880-1940', in Credit, Markets and the Agrarian Economy of Colonial India. Delhi: Oxford University Press, 1994.

Bonnett, Alastair. 'How the British working class became white: The symbolic (re)formation of racialized capitalism', Journal of Historical Sociology, 11:3 (September 1998): 316-40.

Brawley, Sean. The White Peril: Foreign Relations and Asian Immigration to Australasia and North America, 1919-78. Sydney: UNSW Press, 1995.

Briggs, Asa. The Age of Improvement, 1783-1867. London: Longmans, Green, 1959.

Brown, Judith. Modern India: The Origins of an Asian Democracy. Oxford: Oxford University Press, 1985.

Buchighnani, Norman and Indra, Doreen M. Continuous Journey: A Social History of South Asians in Canada. Toronto: McClelland and Stewart, 1988.

Burton, Antoinette. At the Heart of the Empire: Indians and the Colonial Encounter in Late-Victorian Britain. Berkeley and Los 


\section{‘THE BETTER CLASS’ OF INDIANS}

Angeles: University of California Press, 1998.

_ Burdens of History: British Feminists, Indian Women, and Imperial Culture, 1865-1915. Chapel Hill: University of North Carolina Press, 1994.

- Institutionalizing imperial reform: The Indian Magazine and lateVictorian colonial politics', in David Finkelstein and Douglas M. Peers (eds), Negotiating India in the Nineteenth-Century Media. Basingstoke, UK: Macmillan Press, 2000.

Cannadine, David. Ornamentalism: How the British Saw Their Empire.

Oxford: Oxford University Press, 2001.

The Rise and Fall of Class in Britain. New York: Columbia University Press, 1999.

Cartwright, Frederick F. The Development of Modern Surgery. New York: Thomas Y. Crowell, 1967.

Chakravarti, Uma. Rewriting History: The Life and Times of Pandita Ramabai. New Delhi: Kali for Women, 1998.

Chandrasekhar, S. From India to Canada: A Brief History of Immigration; Problems of Discrimination, Admission and Assimilation. La Jolla, CA: Population Review, 1986.

Cohn, Bernard S. 'Representing authority in Victorian India', in Eric Hobsbawm and Terence Ranger (eds), The Invention of Tradition. Cambridge: Cambridge University Press, 1983.

- 'The census, social structure and objectification in South Asia', in An Anthropologist Among the Historians and Other Essays. Delhi: Oxford University Press, 1987.

Colley, Linda. 'Britishness and otherness: An argument', Journal of British Studies, 31:4 (1992): 309-29.

Compton, J. M. 'Indians and the Indian Civil Service, 1853-1879: A study in national agitation and imperial embarrassment', Journal of the Royal Asiatic Society of Great Britain and Ireland, 3/4 (1967): 99-113.

_ 'Open competition and the Indian Civil Service, 1854-1876', English Historical Review, 83:327 (April 1968): 264-84.

Cox, Jeffrey. Imperial Fault Lines: Christianity and Colonial Power in India, 1818-1940. Stanford: Stanford University Press, 2002.

- 'Religion and imperial power in nineteenth-century Britain', in Richard Helmstadter (ed.), Freedom and Religion in the Nineteenth Century. Stanford: Stanford University Press, 1997.

- The English Churches in a Secular Society: Lambeth, 1870-1930. Oxford: Oxford University Press, 1982.

'The missionary movement', in D. G. Paz (ed.), NineteenthCentury English Religious Traditions: Retrospect and Prospect. Westport, CT: Greenwood Press, 1995. 


\section{BIBLIOGRAPHY}

Crossick, Geoffrey. 'From gentlemen to residuum: Languages of social description in Victorian Britain', in Penelope J. Corfield (ed.), Language, History and Class. Oxford: Basil Blackwell, 1991.

Crow, Duncan. The Victorian Woman. London: Allen and Unwin, 1971.

Crowther, M. A. The Workhouse System, 1834-1929: The History of an English Social Institution. Athens, GA: University of Georgia Press, 1982.

D'Cruze, Shani. 'Women and the family', in June Purvis (ed.), Women's History: Britain, 1850-1945. New York: St Martin's Press, 1995.

Davis, Mike. Late Victorian Holocausts: El Niño Famines and the Making of the Third World. London: Verso, 2001.

Deslandes, Paul R. "The foreign element": Newcomers and the rhetoric of race, nation, and empire in "Oxbridge" undergraduate culture, 1850-1920', Journal of British Studies, 37 (1998): 54-90.

- Oxbridge Men: British Masculinity and the Undergraduate Experience, 1850-1920. Bloomington: Indiana University Press, 2005.

Dewey, C. J. 'The education of a ruling caste: The Indian Civil Service in the era of competitive examination', English Historical Review, 88:347 (1973): 262-85.

Dirks, Nicholas. 'The invention of caste', Social Analysis, 25 (1989): 42-52.

Elshtain, Jean Bethke. Public Man, Private Woman: Women in Social and Political Thought. Princeton, NJ: Princeton University Press, 1981.

Emsley, Clive. Crime and Society in England, 1750-1900, 2nd edn. London: Longman, 1996.

Fischer, Louis. The Life of Mahatma Gandhi. Toronto: Macmillan, 1950.

Fisher, Michael H. Counterflows to Colonialism: Indian Travellers and Settlers in Britain, 1600-1857. Delhi: Permanent Black, 2004.

Green, Jeffrey. Black Edwardians: Black People in Britain, 1901-1914. London: Frank Cass, 1998.

Gorin, George. History of Ophthalmology. Wilmington, DE: Publish or Perish, 1982.

Grover, B. L. A Documentary Study of British Policy Towards Indian Nationalism, 1885-1909. Delhi: Shri Kishan, 1967.

Guha, Ranajit. A Rule of Property for Bengal: An Essay on the Idea of Permanent Settlement. Durham, NC: Duke University Press, 1996.

— Subaltern Studies I: Writings on South Asian History and Society. Delhi: Oxford University Press, 1982.

Hamer, D. A. John Morley: Liberal Intellectual in Politics. Oxford: Clarendon Press, 1968. 
Hardy, Anne. Health and Medicine in Britain Since 1860. New York: Palgrave, 2001.

Harrison, Mark. 'Was there an oriental renaissance in medicine? The evidence of the nineteenth-century medical press, The Indian Magazine and late-Victorian colonial politics', in David Finkelstein and Douglas M. Peers (eds), Negotiating India in the NineteenthCentury Media. Basingstoke: Macmillan Press, 2000.

Hasian, Marouf Arif. The Rhetoric of Eugenics in Anglo-American Thought. Athens, GA: University of Georgia Press, 1996.

Herz, Nicole. 'It's personal before it's political: Ambition and angst in the lives of Indian civil servants, 1880-1950', Essays in History, 40 (1998): http://etext.lib.virginia.edu/journals/EH/EH40/herz40.html (accessed 8 November 2005).

Hobbes, Thomas. Leviathan. London: J. M. Dent and Sons, 1914.

Hobsbawm, E. J. The Age of Revolutions, 1789-1848. London: Weidenfeld and Nicolson, 1962.

Honey, J. R. de S. Tom Brown's Universe: The Development of the English Public School in the Nineteenth Century. New York: Quadrangle, 1977.

Howe, Stephen. Ireland and Empire: Colonial Legacies in Irish History and Culture. Oxford: Oxford University Press, 2000.

Hudson, Pat. 'Women and industrialization', in June Purvis (ed.), Women's History: Britain, 1850-1945. New York: St Martin's Press, 1995.

Hunt, James D. Gandhi in London. New Delhi: Promilla and Co., 1978. Huttenback, Robert A. Racism and Empire: White Settlers and Colored Immigrants in the British Self-Governing Colonies, 1830-1910. Ithaca: Cornell University Press, 1976.

Ignatiev, Noel. How the Irish Became White. New York: Routledge, 1995.

Inden, Ronald. 'Orientalist Constructions of India', Modern Asian Studies, 20:3 (1986): 401-46.

Jasanoff, Maya. Edge of Empire: Lives, Culture and Conquest in the East, 1750-1850. New York: Alfred A. Knopf, 2005.

Jensen, Joan M. Passage from India: Asian Indian Immigrants in North America. New Haven: Yale University Press, 1988.

Journal of Colonialism and Colonial History, 3:1 (2002).

Joyce, Patrick. Visions of the People: Industrial England and the Question of Class, 1848-1914. Cambridge: Cambridge University Press, 1991.

Kaminsky, Arnold P. The India Office, 1880-1910. Westport, CT: Greenwood Press, 1986.

Karatani, Rieko. Defining British Citizenship: Empire, Commonwealth and Modern Britain. London: Frank Cass, 2003. 


\section{BIBLIOGRAPHY}

Keith, Arthur Berriedale. A Constitutional History of India, 1600-1935, reprint of 2nd edn. London: Methuen, 1969.

Kirk-Greene, Anthony. Britain's Imperial Administrators, 1858-1966. New York: St Martin's Press, 2000.

Kolff, Dirk. Naukar, Rajput and Sepoy: The Ethnohistory of the Military Labour Market in Hindustan, 1450-1850. Cambridge: Cambridge University Press, 1990.

Lahiri, Shompa. Indians in Britain: Anglo-Indian Encounters, Race and Identity, 1880-1930. London: Frank Cass, 2000.

'British policy towards Indian princes in late-nineteenth and early twentieth-century Britain', Immigrants and Minorities, 15:3 (1996): 214-32.

Lane, Joan. A Social History of Medicine: Health, Healing and Disease in England, 1750-1950. London and New York: Routledge, 2001.

Lawrence, Christopher. Medical Theory, Surgical Practice: Studies in the History of Surgery. London: Routledge, 1992.

Lengel, Ed. 'A "perverse and ill-fated people": English perceptions of the Irish, 1845-52', Essays in History, 38 (1996): http://etext.virginia.edu /journals/EH/EH38/Lengel.html (accessed 1 January 2008).

Lindeborg, Ruth. "The "Asiatic" and the Boundaries of Victorian Englishness', Victorian Studies, 37:3 (1994): 381-404.

Lorimer, Douglas. 'Reconstructing Victorian racial discourse: Images of race, the language of race relations, and the context of black resistance', in Gretchen Holbrook Gerzina (ed.), Black Victorians/ Black Victoriana. New Brunswick, NJ: Rutgers University Press, 2003.

Mackenzie, John M. The Empire of Nature: Hunting, Conservation and British Imperialism. Manchester: Manchester University Press, 1988.

'The imperial pioneer and hunter and the British masculine stereotype in late Victorian and Edwardian times', in J. A. Mangan and James Walvin (eds), Manliness and Morality: Middle-Class Masculinity in Britain and America, 1800-1940. Manchester: Manchester University Press, 1987.

Magubane, Zine. Bringing the Empire Home: Race, Class, and Gender in Britain and Colonial South Africa. Chicago: University of Chicago Press, 2004.

Mallet, Bernard. Sir Louis Mallet: A Record of Public Service and Political Ideals. London: James Nisbet and Co., 1905.

Mangan, J. A. Athleticism in the Victorian and Edwardian Public School: The Emergence and Consolidation of an Educational Ideology. Cambridge: Cambridge University Press, 1981.

The Games Ethic and Imperialism: Aspects of the Diffusion of an Ideal. London: Viking, 1986. 


\section{‘THE BETTER CLASS’ OF INDIANS}

Marshall, P. J. Bengal: The British Bridgehead: Eastern India, 1740-1828. Cambridge: Cambridge University Press, 1987.

Martin, Briton, Jr. New India, 1885: British Official Policy and the Emergence of the Indian National Congress. Berkeley: University of California Press, 1969.

Mathur, Saloni. 'Living ethnological exhibits: The case of 1886', Cultural Anthropology, 15:4 (November 2000): 492-524.

McClintock, Anne. Imperial Leather: Race, Gender, and Sexuality in the Colonial Contest. London: Routledge, 1995.

McLeod, Roy and Lewis Milton (eds). Disease, Medicine, and Empire: Perspectives on Western Medicine and the Experience of European Expansion. London: Routledge, 1988.

Mehrotra, S. R. The Emergence of the Indian National Congress. Delhi: Vikas Publications, 1971.

Metcalf, Thomas R. The Aftermath of Revolt: India, 1857-1870. Princeton: Princeton University Press, 1964.

- Ideologies of the Raj. Cambridge: Cambridge University Press, 1997.

- Land, Landlords, and the British Raj: Northern India in the Nineteenth Century. Berkeley and Los Angeles: University of California Press, 1978.

Misra, B. B. The Bureaucracy in India: An Historical Analysis of Development up to 1947. Delhi: Oxford University Press, 1977.

Moir, Martin I. et al. (eds). J. S. Mill's Encounter with India. Toronto: University of Toronto Press, 1999.

Nicholson, Reynold A. Sir C. J. Lyall, 1845-1920. London: Oxford University Press, n. d.

Noiriel, Gérard. The French Melting Pot: Immigration, Citizenship, and National Identity, trans. Geoffrey de Laforcade. Minneapolis: University of Minnesota Press, 1996.

Omissi, David. "Martial races": Ethnicity and security in colonial India, 1858-1939', War and Society, 9:1 (1991): 1-27.

Pacey, Arnold. Technology in World Civilizations: A Thousand-Year History. Oxford: Oxford University Press, 1990.

Parry, Noel and José. The Rise of the Medical Profession: A Study of Collective Social Mobility. London: Croom Helm, 1976.

Parsons, Gerald. 'Rethinking the missionary position: Bishop Colenso of Natal', in John Wolffe (ed.), Religion in Victorian Britain, Vol. V Culture and Empire. Manchester: Manchester University Press, 1997.

Peers, Douglas M. "The habitual nobility of being": British officers and the social construction of the Bengal army in the early nineteenth century', Modern Asian Studies, 25:3 (1991): 545-59.

Perkin, Harold. The Rise of Professional Society: England Since 1800. London and New York: Routledge, 1989. 


\section{BIBLIOGRAPHY}

Perkin, Joan. Victorian Women. London: John Murray, 1993.

Ramdin, Ron. The Making of the Black Working Class in Britain. Aldershot: Gower Publishing Company, 1987.

Roper, Michael and John Tosh (eds). Masculinities in Britain since 1800. London: Routledge, 1991.

Schneer, Jonathan. London 1900: The Imperial Metropolis. New Haven: Yale University Press, 1999.

Scott, Joan W. 'Gender: A useful category of historical analysis', The American Historical Review, 91:5 (1985): 1053-75.

Searle, G. R. Eugenics and Politics in Britain, 1900-1914. London: Noordhoff International Publishing, 1976.

Sen, Satadru. Migrant Races: Empire, Identity and K. S. Ranjitsinjhi. Manchester: Manchester University Press, 2005.

Sherif, M. A. Searching for Solace: A Biography of Abdullah Yusuf Ali, Interpreter of the Qur'an. Kuala Lumpur: Islamic Book Trust, 1994.

Shorter, Edward. Doctors and Their Patients: A Social History. New Brunswick, NJ: Transaction Publishers, 1985.

Simon, Bian and Ian Bradley (eds). The Victorian Public School: Studies in the Development of an Educational Institution. Dublin: Gill and Macmillan, 1975.

Sinha, Mrinalini. 'Britishness, clubbability, and the colonial public sphere', in Tony Ballantyne and Antoinette Burton (eds), Bodies in Contact: Rethinking Colonial Encounters in World History. Durham, NC: Duke University Press, 2005.

- Colonial Masculinity: The 'Manly Englishman' and the 'Effeminate Bengali' in the Late Nineteenth Century. Manchester: Manchester University Press, 1995.

Stanley, Brian. The Bible and the Flag: Protestant Missionaries and British Imperialism in the Nineteenth and Twentieth Centuries. Leicester: Apollos, 1990.

Stokes, Eric. The English Utilitarians and India. London: Clarendon Press, 1959.

Stoler, Ann Laura. 'Making empire respectable: The politics of race and sexual morality in 20th-century colonial cultures', American Ethnologist, 16:4 (November 1989): 634-60.

_ Carnal Knowledge and Imperial Power: Race and the Intimate in Colonial Rule. Berkeley and Los Angeles: University of California Press, 2002.

— Race and the Education of Desire: Foucault's History of Sexuality and the Colonial Order of Things. Durham NC: Duke University Press, 1995.

Tabili, Laura. 'The construction of racial difference in twentieth-century Britain: The Special Restriction (Coloured Alien Seamen) Order, 


\section{‘THE BETTER CLASS’ OF INDIANS}

1925', Journal of British Studies, 33(1) (1994): 54-98.

" "Keeping natives under control": Race segregation and the domestic dimensions of empire, 1920-1939', International Labor and Working-Class History, 44 (1993): 67-78.

Thompson, E. P. The Making of the English Working Class. London: V. Gollancz, 1964.

Torpey, John. The Invention of the Passport: Surveillance, Citizenship and the State. Cambridge: Cambridge University Press, 2000.

Tsuzuki, Cshushichi. H. M. Hyndman and British Socialism. Oxford: Oxford University Press, 1961.

Visram, Rozina. Ayahs, Lascars and Princes: Indians in Britain, 1700-1947. London: Pluto Press, 1986.

— Asians in Britain: 400 Years of History. London: Pluto Press, 2002.

Ward, Peter W. White Canada Forever: Popular Attitudes and Public Policy Toward Orientals in British Columbia. Montreal: McGillQueen's University Press, 1974.

Wilde, Simon. Ranji: A Genius Rich and Strange. London: Kingswood Press, 1990.

Williams, Donovan. The India Office, 1858-1869. Hoshiapur, India: Vishveshvaranand Vedic Research Institute, 1983.

Wolpert, Stanley. Morley and India, 1906-1910. Berkeley: University of California Press, 1967.

A New History of India, 6th edn. Oxford: Oxford University Press, 2000.

Yule, Henry and Burnell, A. C. Hobson-Jobson: a glossary of colloquial Anglo-Indian words and phrases, and of kindred terms, etymological, historical, geographic and discursive, 2nd edn. London: Murray, 1903. 